area, a conclusion already reached by the Wests (1909) and by Pearsall (1932). In the peaty loughs where acid conditions predominate these dissolved solids include a large proportion of vegetable organic matter in a slightly oxidized condition with a small amount of decomposition products, in contrast to the less peaty loughs where the organic matter carried into the loughs is comparatively highly oxidized with a large amount of products of oxidation including nitrates. The general effect of such conditions is the greater proportion of diatoms most noticeable in the calcareous loughs.

\section{'BOG-BUTTER' FROM SKYE}

$T$

HE practice of burying kegs of butter or body fat with the object of preserving or improving the flavour of the product continued in Ireland from an uncertain period of antiquity until the end of the eighteenth century. In Scotland, too, similar kegs of fat have been recovered from the peat bogs, though none of as recent date as some of the Irish finds that have come to light. The preservation of fatty substances has always been a problem of human economy which has only been partially solved in our own times with the advent of cold-storage, and the burying of kegs of fat in deep peat holes and leaving them there for any length of time up to seven years, when the flavour is said to be at its best, was probably a considerable contribution towards its solution.

The particular example now described by Prof. J. Ritchio (Proc. Soc. Antiq. Scotland, 75 ; 1940-41) was discovered by Dr. Hugh Mackay in 1931, while peat was being cut about one mile east of the inn at Kilmaluag at the northerm end of Skye. When found, the wooden keg was embedded in the solid peat bank, being tilted a little to one side. It would seem that it had been lowered into a fairly deep peat hole and for some reason forgotten or lost. The body of the barrel was hewn from a solid piece of wood, as also were the circular lid and bottom, though the diameter of the keg was some 15 inches and the tree from which it was made a birch. The workmanship was excellent, the thickness surprisingly uniform throughout. At the top of the barrel where the rim is otherwise bevelled off there are two upward projections nearly three inches high and each pierced by two holes, through one pair of which a cord could be passed for lowering the keg, while a small stick placed through the lower pair would have held the lid in place. Half-way up the body of the keg and not symmetrically placed on its circumference there are two more projections, this time lug-like, the holes having been burnt through the solid wood. It is suggested that these were useful when the keg was slung over a horse's back.

The mass of buttery fat itself has been analysed, but what it was originally could not be certainly determined. Some hairs were present, however, in the amorphous mass, which were mostly those of cattle, though a few human, dog and horse ones were also identified. On the whole, this would tend to suggest that the fat was originally a true butter.

Various methods were used in attempts to date the find-pollen analysis, associated finds, etc.--but no conclusive results could be given. Considering everything the writers are inclined to ascribe the find to the opening years of the Christian era.

M. C. BurkitT.

\section{MELLON INSTITUTE OF INDUSTRIAL RESEARCH}

$T$ HE twenty-ninth report of the Director of the Mellon Institute of Industrial Research, covering the year ended February 28, 1942, refers to the increase of the industrial research staff from 187 to 205 fellows and from 114 to 150 fellowship assistants engaged on some ninety-five industrial fellowships. Of the eight fellowships terminated during the year, that on carbon blacks as absorbents was concluded by a study of the activation of colloidal carbons with the object of determining their possibilities for use in absorption either in their original form or after treatment. Some carbon blacks prepared in pellet form with a suitable binder and activated by steam showed remarkable increases in their capacities for absorbing vapours and for purifying water.

Special interest is attached to the investigations of the Department for Research in Pure Chemistry, and studies in the chemistry and chemotherapy of modified cinchona alkaloids and related drugs have continued. In experience to date, no beneficial result of quinine cannot be obtained equally well with hydroxyethyl. apocupreine, a drug which is greatly superior to quinine in pneumonia, in infections of the eye and throat and in certain asthmatic conditions. In view of possible difficulty in obtaining adequate supplies, cinchona alkaloids investigations are in progress aiming at the preparation of simpler compounds which can be prepared from more easily available materials. Studies have also been carried out for the twelfth revision of the U.S. Pharmacopeia, and a number of projects have been subsidized by the Mellon Institute at the Institute of Pathology of the Western Pennsylvania Hospital, particularly on the effects of the sulphonamides on the tissues of the host and on the infecting agent in the tissues. A new sulphhydryl preparation ('Hydrosulphosol') has been found to be of value in the treatment of burns, stimulating rapid healing and discouraging infection. Other work has continued on natural resistance and the common cold, and on the role of certain enzymes in the metabolism of oxygen and carbon dioxide.

Particular reference is made to the work of the Industrial Hygiene Foundation, a combined research and service association for health protection in industry which maintains its headquarters at the Mellon Institute; this Foundation was originally known as the Air Hygiene Foundation, the change of name having been made during the past year. The investigations of the Foundation have covered the effect of arc-welding fumes on susceptibility to tuberculosis, the reactions of living tissues to silica granules, the evaluation of X-ray films for use in physical examinations in industry, and on the present exhaust ventilation systems for control of health hazards. Since early in 1941, the Foundation has been studying sickness absenteeism in industry, and fatigue is also receiving constant consideration. Work on aluminium powder as a possible preventative in silicosis is also reviewed in the report.

Of other industrial fellowships completed during the year reference is made to work on new pre-cast concrete units such as columns, girders and hollow floor and wall panels, the speed of erection of which is the basis of their utility, and an investigation on safety fuses initiated in 1930 has also been completed. With regard to fellowship researches in progress, 'Anthrafloss' is a high-grade mineral wool for insulat- 